\section{Vascular Cures}

\section{Wylie Scholar Program}

Subjects: Vascular health

Purpose: Vascular Cures, Wylie Scholar Program is building a pipeline of innovators in vascular health. We provide 3-year career development grants to outstanding young vascular surgeon-scientists who combine active patient care with academic research. The award supports crucial research that enables them to compete for future research funding. Wylie Scholars become North America's world-class vascular surgeon-scientists; many are now chiefs at major academic centers, prominent leaders in the field, and play a key role in our programs. Four Wylie Scholars are on our Scientific Advisory Board and another is leading Project Voice.

Eligibility: Candidates must hold a full-time faculty appointment as a vascular surgeon with active privileges at a medical school accredited by the Liaison Committee on Medical Education in the United States or the Committee for the Accreditation of Canadian Medical Schools in Canada. Only one nomination per institution per year will be considered. The following conditions also must be met: The candidate must hold a valid and current certification from the American Board of Surgery, or the Royal College of Physicians and Surgeons of Canada, in general surgery or vascular surgery. The candidate must be an active, practicing clinical vascular surgeon. The candidate must present convincing evidence of rigorous research training and significant research accomplishments to date. The candidate must not be currently funded by a career development award from the National Institutes of Health, Veterans Affairs, American Heart Association, or similar extramural funding agencies. Concomitant awards similar in size to the Wylie Scholar (e.g. from professional societies such as the American College of Surgeons) must be disclosed and will be considered on an individual basis. The candidate must prepare and present a challenging research plan to be completed during the term of the award. The candidate must have a research mentor who will be an additional resource for his or her research. The Chairman of the Department of Surgery must guarantee that the candidate will have $40 \%$ protected time available to devote to the research investigation, as well as facilities, equipment and resources to execute the proposed studies. The candidate is expected to participate in the Vascular Cures Wylie Scholar award event each year during their research grant tenure. This includes participating in a scientific interchange with Vascular Cures Board of Directors and donors. Up to $C \$ 1,800$ of the annual stipend may be used for travel expenses and one night of lodging.

Level of Study: Junior Faculty

Type: Grant

Value: $\mathrm{C} \$ 150,000$

Length of Study: 3 years

Country of Study: United States of America or Canada

Application Procedure: Apply online

Closing Date: 2 March

Additional Information: vascularcures.org/wylie-scholarprogram-2/

\section{Victoria University}

PO Box 14428, Melbourne, VIC 8001, Australia.

Tel: (61) 99194659

Email: lesley.birch@vu.edu.au

Website: www.vu.edu.au

Contact: Ms Lesley Birch

Victoria University is one of Australia's leading universities, where challenging conventional thinking is not only encouraged but also expected. It has 11 campuses and sites, 46,000 enrolled students, 7,900 international students from over 30 countries, 700 courses in higher education and TAFE. 


\section{Victoria University Research Scholarships}

Purpose: To support students undertaking Master's research and research Doctorates

Eligibility: Open to citizens or permanent residents of Australia who have achieved Honours 1 or equivalent having studied at or currently studying at Victoria University of Technology

Level of Study: Postgraduate

Type: Scholarship

Value: AU $\$ 22,500$

Length of Study: 1 year

Frequency: Annual

Study Establishment: Victoria University

Country of Study: Australia

Closing Date: 31 October

\section{For further information contact:}

Tel: $\quad$ (61) 396884659

Fax: (61) 396884559

Email: Lesley.Birch@vu.edu.au

\section{Victoria University of Wellington}

PO Box 600, Wellington 6140, New Zealand.

Tel: $\quad$ (64) 44635113,44721000

Email: scholarships-office@vuw.ac.nz

Website: www.vuw.ac.nz

Contact: Scholarship Office

Victoria University of Wellington is New Zealand's most research intensive university, located in New Zealand's compact vibrant capital city. It is one of the oldest universities in New Zealand. Victoria has produced Nobel prize winning scholars and a Booker Prize winner. Victoria provides excellent supervision, facilities and financial support for postgraduate research. Scholarships are available in all disciplines.

\section{Therle Drake Postgraduate Scholarship}

Purpose: The scholarship is for postgraduate classical performance overseas study and application should be made in the year for which the project is planned. While the terms of the bequest are that preference be given to a piano student, other applicants will be considered

Eligibility: The project will normally involve the student attending a short course (up to four weeks), or attending and/or participating in concerts and/or masterclasses in
Europe, North America or Australia. The project should be complementary to the current postgraduate course of study at the NZSM and create minimal disruption to any structured course work.

Level of Study: Postgraduate

Type: Scholarship

Value: Approximately US\$12,000, subject to funds available

Length of Study: 1 year

Frequency: Annual

Country of Study: Any country

No. of awards offered: Varies

Closing Date: 1 November

Funding: Private

Additional Information: www.scholarshipsads.com/therledrake-postgraduate-scholarship-for-international-students-innew-zealand-2019/

\section{For further information contact:}

Tel: $\quad$ (64) 44635557

Email: scholarships-office@vuw.ac.nz,pg-research@vuw. ac.nz, summer-research@vuw.ac.nz

\section{Vice-Chancellor's Strategic Doctoral Research Scholarships}

Eligibility: Applicants are expected to have the equivalent of a New Zealand First Class Honours Degree and skills and research experience appropriate for the topic

Level of Study: Doctorate, Research

Type: Scholarship

Value: NZ\$20,000 per year

Frequency: Annual

Study Establishment: Victoria University

Country of Study: New Zealand

Application Procedure: Application forms must be forwarded to the scholarships manager. Topics are advertised at www.ac.nz/scholarships from 1 March each year

No. of awards offered: 35

Closing Date: 15 May

Contributor: Victoria University

No. of awards given last year: 10

No. of applicants last year: 35

\section{For further information contact:}

Scholarships Office, Office of Research and Postgraduate Study, Victoria University of Wellington, PO Box 600, Wellington 6140, New Zealand.

Tel: $\quad$ (64) 44635113 or 44637493

Email: Scholarships-Office@vuw.ac.nz 


\section{Victoria Hardship Fund Equity Grants for International Students in New Zealand}

Purpose: These grants are to encourage students who are facing financial hardship to continue in their studies at Victoria University. The Grants are intended to assist with ongoing costs related to study. They are not intended for tuition fees Eligibility: Scholarships are open to all students who are studying at Victoria University of Wellington including domestic, international, undergraduate, postgraduate, parttime and full-time students. The Victoria University has a tradition of fostering strong global links in teaching and research and program of national significance and international quality. Applicants must be enrolled in the trimester they are applying for e.g. students who apply for round 1 must be enrolled in trimester 1 of the same year. The grants will be awarded on the basis of financial need and satisfactory academic commitment and progress. Factors taken into consideration when assessing financial need could include - high course costs, high transport costs, medical conditions or disability preventing part-time work, family to support, any other relevant circumstances

Level of Study: Graduate

Type: Grant

Value: Scholarship upto NZ $\$ 2,000$ will be provided

Frequency: Annual

Country of Study: Any country

Application Procedure: Application can be processed through online mode with the below link. www.victoria.ac.nz Closing Date: 18 February

Funding: Private

Additional Information: scholarship-positions.com/ victoria-hardship-fund-equity-grants-international-studentsnew-zealand/2018/12/20/

\section{For further information contact:}

Victoria University of Wellington, PO Box 600, Wellington 6140, New Zealand.

Tel: (64) 44635557

Email: info@victoria.ac.nz

\section{Victoria Tongarewa Scholarship}

Purpose: Scholarships for study in the following year will be awarded competitively on the basis of academic excellence. Scholarships will be credited to tuition fees. Shortlisted candidates may be requested to undertake a skype interview Eligibility: Scholarship is available for pursuing Undergraduate and postgraduate degree

Level of Study: Postgraduate

Type: Scholarship
Value: US $\$ 10,000$

Length of Study: 1 year

Frequency: Annual

Country of Study: Any country

Closing Date: 31 October

Funding: International office

Additional Information: www.scholarshipsads.com/victoriatongarewa-scholarship-at-victoria-university-of-wellington-innew-zealand-2019/

\section{For further information contact:}

Tel: (64) 44635557

\section{Wellington Graduate Award}

Purpose: The Wellington Graduate Award encourages undergraduate students to proceed to graduate study and to research degrees

Eligibility: Applicants are expected to have achieved a minimum A grade average (GPA 8.0) at 300-level or above however, the number offered are based on the funds available determining the final minimum GPA requirement in any one year.

Level of Study: Postgraduate

Type: Scholarship

Value: Value of US $\$ 5,000$

Length of Study: 1 year

Frequency: Annual

Study Establishment: Victoria University

Country of Study: Any country

No. of awards offered: Varies

Closing Date: 1 November

Contributor: Victoria University

Additional Information: www.wgtn.ac.nz/scholarships/ scholarships-office

\section{For further information contact:}

Scholarships Office, Office of Research and Postgraduate Study, Victoria University of Wellington, PO Box 600, Wellington 6140, New Zealand.

Tel: (64) 44635557

Email: scholarships-office@vuw.ac.nz,pg-

research@vuw.ac.nz

\section{Wellington Master's by Thesis Scholarship}

Purpose: To encourage postgraduate research at Victoria University of Wellington, the University offers scholarships to students about to begin a full-time, research-focussed Master's degree 
Eligibility: Applications are sought from those who are eligible at the time of application, or who will have become eligible at the start of Trimester 2 the following year, to enrol for a Master's degree by thesis worth 90 points or more. In some cases this will be Part 2 of a two-year Master's degree and will usually have the course code 591. Applicants undertaking a 180 point Master's degree will not be eligible for this scholarship. Applicants would normally be expected to have completed a Bachelor's degree or Master's degree Part 1 demonstrating academic achievement equivalent to a First-Class Honours degree from a New Zealand University. Scholarships will be awarded solely on the basis of academic merit by the University Research Scholarships Committee, a sub-committee of the University Research Committee.

Level of Study: Postgraduate

Type: Scholarship

Value: US\$15,000 tax free stipend

Length of Study: 1 year

Frequency: Annual

Study Establishment: Victoria University

Country of Study: Any country

No. of awards offered: Varies

Closing Date: 1 November

Contributor: Victoria University

Additional Information: www.wgtn.ac.nz/scholarships/cur rent/victoria-masters-by-thesis-scholarship

\section{For further information contact:}

Scholarships Office, Office of Research and Postgraduate Study, Victoria University of Wellington, PO Box 600, Wellington 6140, New Zealand.

Tel: (64) 44635557

Email: scholarships-office@vuw.ac.nz,pg-research@vuw. ac.nz

\section{Villa I Tatti and the Museo Nacional del Prado}

Florence, Italy and Madrid, Spain.

Email:_fellowships@itatti.harvard.edu

Website: itatti.harvard.edu/

Villa I Tatti - The Harvard University Center for Italian Renaissance Studies (Florence, Italy) and the Museo Nacional del Prado (Madrid, Spain)

\section{Tatti/Museo Nacional del Prado Joint Fellowship}

Subjects: These fellowship are for scholars specializing in art history, with preference given to advanced research projects that address the relationship between Spain and Italy (including transnational connections and dialogues with Latin America) during the Renaissance, broadly understood historically to include the period from the 14th to the 17th century.

Purpose: A fellowship designed to support early and mid-career scholars in the field of art history, with preference given to advanced research projects that address the relationship between Spain and Italy (including transnational connections and dialogues with Latin America) during the Renaissance, broadly understood historically to include the period from the 14 th to the 17 th century.

Eligibility: Applicants must have their $\mathrm{PhD}$ certificate by the time they apply. They must be conversant in English and Spanish and have at least a reading knowledge of Italian, with a solid background in Italian and/or Spanish and Latin American studies. Each successful candidate must be approved by both the Museo Nacional del Prado and Villa I Tatti and will spend the fall term (mid-September - mid-December) at the Museo del Prado in Madrid supported by Centro de Estudios de Europa Hispánica and the spring term (January-June) at Villa I Tatti in Florence. During both terms, it must be possible for Fellows to carry out most of their research with the resources available in the city where they are resident. Priority will be given to applicants with no previous association with either I Tatti or the Museo del Prado.

Level of Study: Postdoctorate

Type: Residential Fellowship

Value: The stipend for the autumn semester in Madrid is $€ 3,000$ per month, supported by the Centro de Estudios de Europa Hispánica. The stipend for the spring semester in Florence is US $\$ 4,000$ per month, plus a one-time supplement (maximum US\$1,500) towards relocation expenses. An additional US $\$ 1,000$ per month will be offered to offset rental costs, if applicable.

Length of Study: One academic year

Frequency: Annual

Country of Study: Fellows will spend the fall tsemester (September - December) in Madrid and the spring semester (January-June) in Florence.

No. of awards offered: 1

Closing Date: 15 November

Contributor: The semester at the Prado in Spain is made possible with the support of the Centro de Estudios de Europa Hispánica (CEEH)

Additional Information: itatti.harvard.edu/fellowships

\section{For further information contact:}

itatti.harvard.edu/i-tattimuseo-nacional-del-prado-joint-fellow ship. 


\section{Villa I Tatti and the Warburg Institute School of Advanced Study}

Florence, Italy and London, England.

Email:_fellowships@itatti.harvard.edu

Website: itatti.harvard.edu/

warburg.sas.ac.uk/

Villa I Tatti - The Harvard University Center for Italian Renaissance Studies (Florence, Italy) and the Warburg Institute School of Advanced Study at the University of London, England.

\section{Warburg - I Tatti Joint Fellowship}

Subjects: A joint, residential fellowship for scholars in the field of history, with preference given to advanced research projects that address the history of science and knowledge related to early modern Italy, including transnational connections between Italy and other cultures. Scholars can also apply to work on the transmission and circulation of ideas, objects, and people during the Renaissance, into and beyond the Italian peninsula, or on the historiography of the Italian Renaissance, including the rebirth of interest in the Renaissance in later periods.

Purpose: Villa I Tatti - The Harvard University Center for Italian Renaissance Studies in Florence, Italy, and the Warburg Institute School of Advanced Study at the University of London offer a joint, residential fellowship for early and mid-career scholars in the field of history, with preference given to advanced research projects that address the history of science and knowledge related to early modern Italy, including transnational connections between Italy and other cultures. Scholars can also apply to work on the transmission and circulation of ideas, objects, and people during the Renaissance, into and beyond the Italian peninsula, or on the historiography of the Italian Renaissance, including the rebirth of interest in the Renaissance in later periods.

Eligibility: Scholars must have a $\mathrm{PhD}$ to apply and may not may not be working on a second doctorate at the time of application. Applicants must be conversant in English and have at least a reading knowledge of Italian, with a solid background in Italian Renaissance Studies. Each successful candidate must be approved by both the Warburg Institute and Villa I Tatti and will spend the fall term (September December) at the Warburg Institute in London and the spring term (January-June) at Villa I Tatti in Florence. During both terms, It must be possible for Fellows to carry out most of their research with the resources available in the city where they are resident for the fellowship. Priority will be given to applicants with no previous association with either I Tatti or the Warburg Institute. Applications will not be accepted from candidates proposing to revise their doctoral dissertation for publication.

Level of Study: Postdoctorate

Type: Residential Fellowship

Value: The stipend for the autumn semester at the Warburg is $£ 1,500$ per month. The stipend for the spring semester at I Tatti is US $\$ 4,000$ per month, plus a one-time supplement (maximum US\$1,500) towards relocation expenses. An additional US $\$ 1,000$ per month will be offered to offset rental costs, if applicable.

Length of Study: One academic year

Frequency: Annual

Country of Study: Fellows will spend the fall term (September - December) at the Warburg Institute in London and the spring term (January-June) at Villa I Tatti in Florence.

No. of awards offered: 1

Closing Date: 15 November

Additional Information: itatti.harvard.edu/fellowships

\section{For further information contact:}

itatti.harvard.edu/warburgi-tatti-joint-fellowship.

\section{Villa I Tatti: The Harvard University Center for Italian Renaissance Studies}

Florence, Italy.

Email: fellowships@itatti.harvard.edu

Website: itatti.harvard.edu/

Contact: Angela Lees, Administrative Assistant

Villa I Tatti is the Harvard University Center for Italian Renaissance Studies in Florence, Italy.

\section{Berenson Fellowship}

Subjects: Post-doctoral reasearch on "Italy in the World." Projects should address the transnational dialogues between Italy and other cultures (e.g. Latin American, Mediterranean, African, Asian etc.) during the Renaissance, broadly understood historically to include the period from the 14th to the 17 th century. 
Purpose: A fellowship to support post-doctoral research of scholars who explore "Italy in the World." Projects should address the transnational dialogues between Italy and other cultures (e.g. Latin American, Mediterranean, African, Asian etc.) during the Renaissance, broadly understood historically to include the period from the 14th to the 17th century.

Eligibility: At the time of application, scholars must have a PhD They may not be working on a second $\mathrm{PhD}$ at the time of application. Applicants must be conversant in English and have familiarity with Italian. Priority will be given to early and mid-career scholars. I Tatti welcomes applications from scholars from all nations and gives special consideration to candidates without regular access to research materials and facilities in Italy.

Level of Study: Postdoctorate

Type: Residential Fellowship

Value: NZ $\$ 4,200$ per month, plus a one-time supplement (maximum, NZ\$1,500) towards relocation expenses. When possible, a one-bedroom apartment will be set aside for the Fellow's use, rent free, but with charges for utilities. If an apartment is not available, NZ $\$ 1,000$ per month will be offered to help offset rental costs.

Length of Study: 4-6 months

Frequency: Annual

Country of Study: Italy

No. of awards offered: Up to 4

Closing Date: 15 November

Contributor: The Berenson Fellowship is made possible by The Lila Wallace - Reader's Digest Fund

Additional Information: itatti.harvard.edu/fellowships

\section{For further information contact:}

itatti.harvard.edu/berenson-fellowship.

\section{Craig Hugh Smyth Fellowship}

Subjects: The Craig Hugh Smyth Fellowship is designed for curators and conservators pursuing advanced research in any aspect of the Italian Renaissance.

Purpose: A fellowship designed for curators and conservators pursuing advanced research in any aspect of the Italian Renaissance.

Eligibility: Applicants should be scholars who work for an educational or cultural institution as a curator or conservator. They may apply to carry out research on behalf of their home institution, or propose projects relating to their personal research interests. Applicants must be conversant in English and have familiarity with Italian. Priority will be given to early and mid-career scholars. It must be possible for applicants to carry out most of their research in Florence. I Tatti welcomes applications from scholars from all nations and gives special consideration to candidates without regular access to research materials and facilities in Italy.

Type: Residential Fellowship

Value: US $\$ 4,200$ per month, plus a one-time supplement (maximum, US\$1,500) towards relocation expenses. When possible, a one-bedroom apartment will be set aside for the Fellow's use, rent free, but with charges for utilities. If an apartment is not available, US $\$ 1,000$ per month will be offered to help offset rental costs.

Length of Study: 4-6 months

Frequency: Annual

Country of Study: Italy

No. of awards offered: 2

Closing Date: 15 November

Additional Information: itatti.harvard.edu/fellowships

\section{For further information contact:}

itatti.harvard.edu/craig-hugh-smyth-fellowship.

\section{David and Julie Tobey Fellowship}

Subjects: This fellowship supports research on drawings, prints, and illustrated manuscripts from the Italian Renaissance, and especially the role that these works played in the creative process, the history of taste and collecting, and questions of connoisseurship. Proposals on a variety of subjects with a substantive component of research on drawings, prints, and illustrated manuscripts done on paper or parchment types are welcome.

Purpose: A fellowship to support post-doctoral research on drawings, prints, and illustrated manuscripts from the Italian Renaissance, and especially the role that these works played in the creative process, the history of taste and collecting, and questions of connoisseurship.

Eligibility: Scholars must have a $\mathrm{PhD}$ to apply and may not may not be working on a second doctorate at the time of application. They must be conversant in English and have familiarity with Italian. Priority will be given to early and mid-career scholars. It must be possible for applicants to carry out most of their research in Florence. I Tatti welcomes applications from scholars from all nations and gives special consideration to candidates without regular access to research materials and facilities in Italy.

Level of Study: Postdoctorate

Type: Residential Fellowship

Value: US $\$ 4,200$ per month, plus a one-time supplement (maximum, US\$1,500) towards relocation expenses. When possible, a one-bedroom apartment will be set aside for the Fellow's use, rent free, but with charges for utilities. If an apartment is not available, US $\$ 1,000$ per month will be offered to help offset rental costs. 
Length of Study: 4-6 months

Frequency: Annual

Country of Study: Italy

No. of awards offered: 1

Closing Date: 15 November

Additional Information: itatti.harvard.edu/fellowships

\section{For further information contact:}

itatti.harvard.edu/david-and-julie-tobey-fellowship.

\section{Fellowship in the Digital Humanities}

Subjects: Projects can address any aspect of the Italian Renaissance, broadly understood historically to include the period from the 14th to the 17th century, and geographically to include transnational dialogues between Italy and other cultures (e.g. Latin American, Mediterranean, African, Asian, etc.). Projects should apply digital technologies such as mapping, textual analysis, visualization, or the semantic web to topics in fields such as art and architecture, history, literature, material culture, music, philosophy, religion, and the history of science.

Purpose: A fellowship to support research of scholars in the humanities or social sciences, librarians, archivists, and data science professionals whose research interests or practice cut across traditional disciplinary boundaries and actively employ technology in their work.

Eligibility: Applicants must be conversant in English and have familiarity with Italian. At the time of application, a $\mathrm{PhD}$ is required for scholars in the humanities and social sciences. A Master's degree is required for librarians, archivists, and data science professionals. A background in programming, library sciences, computer graphics, computational linguistics, or other fields relevant to digital humanities research is highly desirable. Candidates should possess the technical skills to carry out their project at the time of application, and it must be possible for applicants to carry out most of their research in Florence. Priority will be given to early and mid-career scholars. I Tatti welcomes applications from scholars from all nations and gives special consideration to candidates without regular access to research materials and facilities in Italy.

Level of Study: A PhD is required for scholars in the humanities and social sciences. A Master's degree is required for librarians, archivists, and data science professionals.

Type: Residential Fellowship

Value: US $\$ 4,200$ per month, plus a one-time supplement (maximum, US $\$ 1,500)$ towards relocation expenses. When possible, a one-bedroom apartment will be set aside for the Fellow's use, rent free, but with charges for utilities. If an apartment is not available, US $\$ 1,000$ per month will be offered to help offset rental costs.

Length of Study: 4-6 months

Frequency: Annual

Country of Study: Italy

No. of awards offered: Up to 4

Closing Date: 15 November

Contributor: The Fellowship in the Digital Humanities is generously supported in part by the Samuel H. Kress Foundation.

Additional Information: itatti.harvard.edu/fellowships

\section{For further information contact:}

A link to the application will be available at itatti.harvard.edu/ fellowship-digital-humanities.

\section{Tatti Fellowship}

Subjects: Post-doctoral research in any aspect of the Italian Renaissance, broadly understood historically to include the period from the 14th to the 17 th century and geographically to include transnational dialogues between Italy and other cultures (e.g. Latin American, Mediterranean, African, Asian etc.).

Purpose: A Fellowship to support post-doctoral research in any aspect of the Italian Renaissance.

Eligibility: Scholars must hold a $\mathrm{PhD}$, dottorato di ricerca, or an equivalent degree. They must be conversant in either English or Italian and able to understand both languages. They should be in the early stages of their career, having received a PhD between 2010-2020 and have a solid background in Italian Renaissance studies. Candidates may not be working on a second $\mathrm{PhD}$ at the time of application. In the event that a candidate holds two doctoral degrees, the eligibility dates $(\mathrm{PhD}$ certificate dated between January 1, 2010 and December 31,2020, inclusive) apply to the more recent degree.

Level of Study: Postdoctorate

Type: Residential Fellowship

Value: US $\$ 60,000$, plus relocation supplement and housing or housing supplement

Length of Study: 1 year

Frequency: Annual

Country of Study: Italy

No. of awards offered: 15

Closing Date: 15 October

Additional Information: itatti.harvard.edu/fellowships

\section{For further information contact:}

itatti.harvard.edu/i-tatti-fellowship. 


\section{Mellon Fellowship in Digital Humanities}

Eligibility: A PhD is required for scholars in the humanities and social sciences; in exceptional cases, applications from advanced $\mathrm{PhD}$ (ABD) students will be considered. A Master's degree is required for librarians, archivists, and data science professionals. A background in programming, library sciences, computer graphics, computational linguistics, or other fields relevant to digital humanities research is highly desirable. Candidates should possess the technical skills to carry out their project at the time of application

Type: Residential fellowships

Value: Up to US $\$ 4,000$ per month plus a one-time supplement (Max: US\$1,500)

Length of Study: 4 to 6 months

Frequency: Annual

Country of Study: Italy

Application Procedure: Please check at itatti.harvard.edu/ mellon-fellowship-digital-humanities

Closing Date: 14 December

Funding: Foundation

Contributor: Andrew W. Mellon Foundation

Additional Information: www.sas.rochester.edu/humani ties/fellowships/mellon.html

\section{For further information contact:}

Tel: (1) 5852759025

Email: morris.eaves@rochester.edu

\section{Villa I Tatti - Bogaziçi University Joint Fellowship}

Subjects: This fellowship focusses on the interaction between Italy and the Byzantine Empire (ca. 1300 to ca. 1700) and aims to foster the development of research on Late ByzantineItalian relations by supporting early-career scholars whose work explores Byzantium's cross-cultural contacts in the late medieval and early modern Mediterranean world through the study of art, architecture, archaeology, history, literature, material culture, music, philosophy, religion, or science.

Purpose: Villa I Tatti - The Harvard University Center for Italian Renaissance Studies (VIT, Florence) and the Byzantine Studies Research Center of Bogaziçi University (BSRC, Istanbul) offer a joint, residential fellowship to support research on the interaction between Italy and the Byzantine Empire (ca. 1300 to ca. 1700). This collaboration aims to foster the development of research on Late Byzantine-Italian relations by supporting early-career scholars whose work explores Byzantium's cross-cultural contacts in the late medieval and early modern Mediterranean world through the study of art, architecture, archaeology, history, literature, material culture, music, philosophy, religion, or science.
Eligibility: The VIT-BSRC Joint Fellowship is offered for candidates who have received a PhD in or after 2010. Candidates must be conversant in English and have at least a reading knowledge of Italian. They must have a solid background in Italian Renaissance and/or Byzantine Studies. Each successful candidate must be approved by both the BSRC and VIT and will spend the fall term (September - December) at Bogaziçi University in Istanbul and the spring term (JanuaryJune) at Villa I Tatti in Florence. During both terms, it must be possible for Fellows to carry out most of their research with the resources available in the city where they are resident. Priority will be given to applicants with no previous association with VIT or BSRC.

Level of Study: The VIT-BSRC Joint Fellowship is offered for candidates who have received a $\mathrm{PhD}$ in or after 2010.

Type: Residential Fellowship

Value: The stipend for the autumn semester in Istanbul is US $\$ 1,800$ per month, plus a one-time supplement (maximum US\$1,500) towards airfare to/from Istanbul. The stipend for the spring semester in Italy is US $\$ 4,200$ per month plus a one-time supplement (maximum US $\$ 1,500$ ) towards relocation expenses. An additional US $\$ 1,000$ per month will be offered to offset rental costs, if applicable.

Length of Study: One academic year.

Frequency: Annual

Country of Study: Fellows will spend the fall term (September - December) in Istanbul and the spring term (January - June) in Florence.

No. of awards offered: 1

Closing Date: 15 November

Additional Information: itatti.harvard.edu/fellowships

\section{For further information contact:}

itatti.harvard.edu/i-tatti-bogazici-joint-fellowship.

\section{Wallace Fellowship}

Subjects: Post-doctoral research on historiography and impact of the Italian Renaissance in the Modern Era (19th21 st centuries). Projects can address the historiography or impact of the Renaissance on any field, including art and architecture, landscape architecture, history, literature, material culture, music, philosophy, religion, and science.

Purpose: A Fellowship to support post-doctoral research on the historiography and impact of the Italian Renaissance in the Modern Era (19th-21st centuries).

Eligibility: At the time of application, scholars must have a PhD They may not be working on a second $\mathrm{PhD}$ at the time of application. Applicants must be conversant in English and have familiarity with Italian. Priority will be given to early and mid-career scholars. It must be possible for applicants to carry out most of their research in Florence. I Tatti welcomes 
applications from scholars from all nations and gives special consideration to candidates without regular access to research materials and facilities in Italy.

Level of Study: Postdoctorate

Type: Residential Fellowship

Value: US\$4,200 per month, plus a one-time supplement (maximum, US\$1,500) towards relocation expenses. When possible, a one-bedroom apartment will be set aside for the Fellow's use, rent free, but with charges for utilities. If an apartment is not available, US $\$ 1,000$ per month will be offered to help offset rental costs.

Length of Study: 4-6 months

Frequency: Annual

Country of Study: Italy

No. of awards offered: Up to 4

Closing Date: 15 November

Contributor: The Wallace Fellowships are made possibly by a generous grant from The Lila Wallace - Reader's Digest Fund.

Additional Information: itatti.harvard.edu/fellowships

\section{For further information contact:}

itatti.harvard.edu/wallace-fellowship.

\section{Vinaver Trust}

45 Albert Street, Western Hill, Durham DH1 4RJ, United Kingdom.

\section{Tel: $\quad$ (44) 1913868898}

Email: geoffreybromiley@btinternet.com

Contact: Dr G.N. Bromiley, Secretary-Treasurer

The Eugène Vinaver Memorial Trust exists to promote research into Arthurian studies, as defined by the International Arthurian Society. It offers subventions to publishers to facilitate the publication of scholarly works; it also offers grants to postgraduate students pursuing research in the Arthurian field.

\section{Barron Bequest}

Subjects: Any field of Arthurian studies

Purpose: To support postgraduate research in Arthurian studies Eligibility: Open to graduates of any university of the United Kingdom and Ireland

Level of Study: Postgraduate research

Type: Grant

Value: $£ 1,250$, payment towards postgraduate fees.

Length of Study: One year. Candidates may apply for further years on a basis of parity with those applying for the first time Frequency: Annual
Study Establishment: Any university in United Kingdom or Ireland

Country of Study: United Kingdom, Republic of Ireland

Application Procedure: For application details, applicants must contact Professor Taylor at the address below

No. of awards offered: Varies, normally one or two per year Closing Date: 30 April

Funding: Private

Contributor: The Eugène Vinaver Memorial Trust

No. of awards given last year: No awards made

No. of applicants last year: 2

Additional Information: www.science-community.org/en/ node/150641

\section{For further information contact:}

Professor JHM Taylor, Garth Head, Penruddock, Penrith, Cumbria CA11 0QU, United Kingdom.

Email: jane.taylor@durham.ac.uk or geoffreybromiley@btinternet.com

\section{Vinod \& Saryu Doshi Foundation}

58, Nariman Bhavan, Nariman Point, Mumbai, Maharashtra 400021, India.

Tel: $\quad$ (91) 61179000

Contact: Vinod \& Saryu Doshi Foundation

The Vinod \& Saryu Doshi Foundation is a non-profit charitable trust that supports initiatives in the fields of Art \& Culture, Education and Community. It seeks to embody the lifelong passions and values of Vinod and Saryu Doshi, who believed that the mind is enriched through education and the spirit through art and culture. They have spent a considerable part of their lives supporting these causes. The Vinod \& Saryu Doshi Foundation initiated these Fellowships to assist Indian nationals who have received acceptance in a University abroad to pursue their post-graduate studies (Masters, Postgraduate diploma/certificate or doctorate) in the field of Liberal Arts \& Sciences. This includes the Humanities, Social Sciences, the Natural Sciences and Mathematics.

\section{Vinod \& Saryu Doshi Foundation Postgraduate Fellowships}

Purpose: The main aim of the fellowship program is to enhance the higher education by giving an opportunity to 
academically bright students who have the drive to succeed but are unable to do so due to their financial challenges. This is a need-based merit Fellowship and abides by the Equal Opportunity and Affirmative Action policy. The maximum amount of the Fellowship will be up to ₹3 lakhs per fellow, which will be payable as a one-time amount

Eligibility: Indian Nationals only

Type: Postgraduate scholarships

Value: Up to ₹3 lakh

Study Establishment: Liberal Arts and Social Sciences

Country of Study: Any country

Application Procedure: Fill in the application form and send the hard copy to Vinod \& Saryu Doshi Foundation

Closing Date: 7 May

Additional Information: For more details please visit the website scholarship-positions.com/vinod-saryu-doshi-found ation-postgraduate-fellowships-liberal-arts-sciences-2017/2017/ 02/20/

\section{For further information contact:}

Email: ericadesouza@vsdf.org

\section{Volkswagen Foundation}

Kastanienallee 35, D-30519 Hannover, Germany.

Tel:

(49) 51183810

Email: info@volkswagenstiftung.de

Contact: VolkswagenStiftung
The Volkswagen Foundation (VolkswagenStiftung) is dedicated to the support of the humanities and social sciences as well as science and technology in higher education and research. It funds research projects in path-breaking areas and provides assistance to academic institutions for the improvement of the structural conditions for their work. In particular, the Foundation perceives its mission in supporting aspiring young researchers and in promoting interdisciplinary and international collaboration.

\section{Volkswagen Foundation Freigeist Fellowships}

Purpose: The Freigeist funding initiative aims to encourage exceptional research personalities to embark on visionary, risk-taking research projects at the intersections between established field of research

Eligibility: Anyone can apply who identifies with the goals of a "Freigeist" Fellowship and whose proposed research projects fits in with the aims pursued by the Freigeist initiative

Level of Study: Doctorate, Postdoctorate

Value: Up to $€ 3,500,000$

Length of Study: 4 years

Frequency: Annual

Country of Study: Germany

Application Procedure: Applications can be submitted online via the Electronic Application System of the Volkswagen Foundation. Instructions are found online

Closing Date: 15 October

Additional Information: scholarships.unimelb.edu.au/awards/ volkswagen-foundation-freigeist-fellowships 